\title{
Firm Size Related to Export Performance
}

Submitted $21 / 10 / 19,1^{\text {st }}$ revision $18 / 11 / 19,2^{\text {nd }}$ revision $19 / 12 / 19$ accepted $24 / 01 / 20$

\author{
Sevdie Alshiqi Bekteshi ${ }^{1}$
}

\begin{abstract}
:
Purpose: This paper provides an overview of exporting firms, as a special case SMEs of the Republic of Kosovo, that are exporters based on relevant academic literature. Empirical evidence reveals that most of the SMEs, have positive relations with some determinants as the number of employees. To verify whether exporting is the first step in the process of internationalization, the findings of this study are linked with related literature on exporting aspects. This also offers a more in-depth understanding of the relation between variables used in the study and export performance.

Design/Methodology/Approach: The paper used quantitative data and face to face interviews with respondents. The descriptive statistics were calculated to give an overview of the distribution, mean and the standard deviation of the dataset. Internal consistency and reliability analysis on a Likert scale was performed using Cronbach's Alpha coefficient.

Findings: The firm size was shown to be highly statistically significant and positively related, indicating that the importance of economies of scale in the probability of being engaged in export is high. The obtained results from the conducted research on SMEs in Kosovo show that the dependency of managers' education and training were corresponding with those attained when testing dependency of managers' age and their international experience.

Practical Implications: Development policy should be made towards the added value and growth of competitive competencies of SMEs in the domestic market and the external market, as well the process to take facilitating steps in exporting promotional activities. Agency for supporting SMEs should coordinate activities to improve the conditions for exporting enterprises by allowing access to public infrastructure.

Originality/Value: This paper is summarized with some specific recommendations for the management of SMEs and for government institutions to improve export performance.
\end{abstract}

Keywords: Firm size, export performance, SMEs, Kosovo.

JEL codes: M10, M16.

Paper type: Research article.

\footnotetext{
${ }^{1}$ University of Prishtina "Hasan Prishtina”, Economic Faculty, Prishtina, Kosovo, sevdie.alshiqi@uni-pr.edu
} 


\section{Introduction}

One of the most important variables studied in business as a determinant of exporting behavior and internationalization process is the company size (Warren and Tesar, 1977). In this article, when we talk about the firm size, we concerned about the number of employees and the sales volume. If someone has decided to export or not, it is not all about abilities but the decision to change the scope and the quality of products or services. There are a lot of internal company factors that are related to an exporting commitment. Some of them are focused on the analysis of internal factors affecting the decision to export (Erdener and Kuan, 1993). Based on existing literature it is quite difficult to measure performance on SMEs' exports because there is no real definition of what is an export success and any clear measurement tool to evaluate progress and its impact on SMEs' performance. This unclear situation leads us to the questions which are the main factors that measure export performance. A lot of economic and noneconomic factors are used to measure the performance of determining factors and export activities. As such are sales growth, rising of the export activity compared to the past production of the firm, export of a significant portion of firm's operations compared to local competitors, the ability to overcome the different entry barriers are often cited by several studies as criteria to measure performance (Katsikeas et al., 2000).

Firms that have more employees are available for increasing export planning and information collection (Samiee, 2002), an entrepreneurial behavior positioning in competitive market (Hozmuller and Stottinger, 1996). Market orientation, based on the ability of the organization to planning, reacting on changes in environment (Rose and Shoham, 2002), changing the structure of export in the organization (Carlos, 2004). From these studies we can conclude that the number of employees influence the way of the organization through trading. The most useful thing is that firm size found as a leading factor in the organization, either as a cause or effect of export development. Other authors give a different relationship between firm size and export, be more competitive globally and to be a big company (Lefebreve and Lefebreve, 2001). One thing being quite essential is that the most positive effect is if we measured the size of the firms based on total sales, and some negative impact if we measured the size of the firms based on the number of employees (Kaynak and Kuan, 1993). The larger firm is more capable in higher investments and to be more competitive as well as to take higher risk (Dholakia and Kapur, 1997).

The positive impact justified by the fact that you have more resources if you have a larger company than this larger company can improve its performance from experience and also from the economies of scale (Maurel, 2009). However small firms with high export performance also exist, but based on initial capital, the larger company has more opportunities to fulfill requirements of international trade by reducing transaction costs (Maurel, 2009). Some other authors found a negative relationship between firm size and exports (James, 2000). Evidence from Australia, Denmark, Italy, Japan and Spain supports this observation: size is of considerable 
importance during the first stages of internationalization but does not seem to be a significant factor afterward (OECD, 1997). Chetty and Hamilton (1993) analyzed more than 111 studies to proof about validity and significance of critical variables among them they confirm that firm size is a causal factor in export success. Also, another objective seems to be associated with time horizon and frame reference managers may utilize to monitor the attainment of their export objectives (Kakkos et al., 2009). To describe better relationship between firm size and export performance, the model proposed is based on control variable, as firm size and number of employees because it is a measure of a firm's resource base, can confound relationships established and may influence the level of interactions and cooperation among firms (Babakus et al., 2006).

\section{Literature Review}

According to Archarungroj and Hoshino (1998) number of employees is not always a good indicator of the firm size, if we have significant differences in export earnings rates, in firms that measure firm size with sales volume. When the number of employees measures capacity Majocchi (2005) finds a healthy relationship between firms size and power export. By comparing firm size with total sales, firm size has a positive effect on export performance but in the other hand if we measured firm size with number of employees we may conclude that firm size has an adverse impact on export performance as in the research by Nazar and Saleem (2011). Mainly, this relationship between export effort and performance and organizational factors such as size, innovation, technology and capacity, will be more clarified in the context of which industries belong to each region (Moen, 2001). In previous studies, the most widely treated variables have been the firm size and its relationship with export performance. We have different kind of approaches in these studies, empirical and theoretical approaches that support or not support each other.

The assumption that larger firms perform better in foreign markets is not supported by empirical research in a study of 14072 Canadian manufacturing firms (Calof, 1995), as far as a study with 8810 Italian exporting firms founded different results, some of them established a positive association of no significant relationship or even negative relationship between them (Cooper and Kleinschmidt, 1985; Bonaccorsi, 1992). Also, firm size expressed with many employees, the experience of the company with export activities, usage of computers and the internet from the company, strategic objectives, and marketing strategy (Rupeika-Apoga and Saksonova, 2018).

The main benefit for all firms in the economy is that increased export will affect in value added of human and physical capital stock in the country (Jordaan and Elita, 2006). Some other internal factors that are quite important and influences export performance are experience related to managerial practice and planning of export strategy (Morgan and Katsikeas, 2012), the capacity of the organization to learn, and level of information technology ( $\mathrm{Lu}$ and Beamish, 2004). Firm size has mixed 
effects, some authors founded a significant relationship and the larger company has more chance to export and to be successful in transporting (Causgil et al., 1987; Cuplan, 1989; Madsen and Servias, 1997; Hindinis, 2019).

Czinkota et al. (1983) did not found any significant relationship between firm size and export activity, while some authors found a negative correlation between these two factors (Geir, 1990). During recent times firm size is the most researched variable, in some researchers with positive effects and in some others with adverse effects, or not significant effects (Chetty and Hamilton, 1993; Aaby et al., 1989). Some positive effects were found mostly when export profit or total firm sales measure size, and in some cases when it estimated by the number of employees (Kayan, 1993). Recent studies found no significant or in some cases adverse effects between the number of years in business and firm's age on export performance (Mallika, 1994; Bodur, 1994). Maybe all the firm's year effects depend on the type of business because these effects of the way of internationalization are mixed in different kind of businesses. In spite of so many realistic studies Gretton and Gabbitas (2003), Kalafsky (2004), Majocchi et al. (2005) Pla-Barber and Alegre (2007) and Verwaal and Donkers (2011), answers have not been established on the significant relationship between these variables.

\section{Empirical Analysis and Research Questions}

This empirical analysis endows with a foundation of the developed research hypothesis, research methodologies that can be used during this part and conceptual model that can be tested empirically. To rich the research question we selected the methods using the quantitative research, following by data collection and developing questionnaire as the most critical stage of the research process to complete the research plan. The descriptive statistics were calculated to give an overview of the distribution, mean and the standard deviation of the data set. Internal consistency and reliability analysis for Likert scale variables was performed using Cronbach's Alpha coefficient. Therefore the research hypothesis is as follows:

H1: Firm size (number of employees) is positively associated with export performance.

\section{Research Methodology}

The data used in this study were obtained from 500 Small and Medium Enterprises operating in Kosovo. The selected exporting company represents 100, which made a total sample of 500 companies. The data was collected using a structured questionnaire and face to face interview was conducted with the main owner/managers or in some cases with financial managers, of the selected companies, for the year 2012. The respondents were asked for degree of agreement with a series of statements on an item measure. The descriptive statistics were calculated to give an overview of the distribution, mean and the standard deviation 
of the data set. Internal consistency and reliability analysis for the Likert scale variables was performed using Cronbach's Alpha coefficient.

In the second stage regression analysis such as linear, Probit and Tobit models were performed in order to find out the relationship and how other factors considered in the study determine and explain the behavior of a company being engaged in export as well as variation of the percentage of export share in the total sales of the company.

\subsection{Dependent and Independent Variables}

In this study, the dependent variable is export performance defined by the participation of export in total sales. The export performance showed a multidimensional formation, validating the complex environment of the structure as suggested by Cavusgil and Zou (1994), Katsikeas et al. (2000), Leonidou et al. (2002), Lages et al. (2005), Lages and Lages (2004). The outcome variable assessed in every research that may be affected by manipulation of the independent variable is named as the dependent variable. The dependent variable is export performance, regarding sales. Export performance in terms of sales have been done in several studies (Majumdar, 1997; Ayan and Percin, 2005; Kneller and Pisu, 2006). In previous studies we have found different indicators that have been used by researchers, but in this research will use sales as the determinant of export performance. Whether this factor has increased or decreased during the last years, as it is stated in the questionnaire.

Testing a large number of independent variables helps in creating more accurate image of overall occurrence (Miller and Friesen, 1984). The other group of variables following the industry which includes as main sectors the manufacturing sector, the service and the trade sector. Moreover, some factors as age, experience and business age are used to measure the SME's growth (Storey, 1994).

\subsection{Descriptive Analysis}

Companies included in this study were relatively new in terms of the year since the establishment was relatively new. However even they are new businesses, they considered exporting as part of their business. The percentage of companies engaged in export was relatively low $(20.2 \%)$ when compared to the total number of companies, included in the sample. As companies were lately established their business experience was fairly low. In regard to the size in terms of the number of personnel working in a company, it was shown that they were rather small to medium companies with up to 250 workers maximum. 
Table 1. Descriptive statistics

\begin{tabular}{llll}
\hline Variable & Unit & Mean & SD \\
\hline Number of employees & Person & 11.19 & 23.87 \\
\hline
\end{tabular}

Study results revealed that companies with number of employees up to 20 had higher propensity to be local that they do have international experience compared to the companies which were bigger in terms of the number of employees. This could also take place due to the bigger proportion (85.6\%) of small companies with 1 up to 20 employees included in the sample. The status of the company being engaged in export was statistically proved to be dependent on the size of the company $\left(\chi^{2}=159.72 ; \mathrm{df}=2 ; \mathrm{p}=0.000\right)$ as shown in Table 2 .

Table 2. Dependency of the internal and external factors importance with the firm size

\begin{tabular}{lllll}
\hline & \multicolumn{5}{l}{ Size of the company (number of employees) } \\
\hline Internal factors & $\chi^{2}$ & Df & Cramer's V & P-value \\
\hline Marketing strategy & 77.43 & 8 & 0.278 & 0.000 \\
Promotion & 16.36 & 8 & 0.128 & 0.037 \\
Place & 14.42 & 8 & 0.120 & 0.071 \\
Product & 12.70 & 8 & 0.113 & 0.122 \\
Price & 13.68 & 8 & 0.117 & 0.090 \\
Innovation & 26.89 & 6 & 0.164 & 0.000 \\
\hline External factors & & & & \\
\hline Infrastructure & 11.38 & 8 & 0.107 & 0.181 \\
Financial barriers & 6.89 & 4 & 0.083 & 0.141 \\
\hline
\end{tabular}

\subsection{Internal Consistency and Reliability Analysis}

Reliability test for Likert scale variables was performed using Cronbach's Alpha coefficient. The mathematical expression of Alpha coefficient is presented as in the following equation:

$$
\alpha=\frac{K}{K-1}\left(1-\frac{\sum_{i=1}^{K} \sigma_{i}^{2}}{\sigma^{2}}\right)
$$

Where, $\mathrm{K}$ stands for the number of questions or the variables;

$\sigma_{i}^{2}$ indicates the variance of answer related to the question $I$;

$\sigma^{2}$ is the variance for the answers of total questions.

The total number of variables measured in Likert scale was 9 (knowledge of foreign languages, marketing strategy, promotion, place, product, price, innovation, infrastructure, and financial barriers). The result of Cronbach's Alpha coefficient (0.799) confirmed a high degree of reliability of the obtained respondents' answers as shown in Table 3. 
Table 31. Reliability statistics for LIKERT scale variables Cronbach's Alpha Cronbach's Alpha Based on Standardized Items $0.799 \quad 0.748$

\subsection{Empirical Model}

In order to explain the behavior of dichotomous dependent variable we first estimated the model that emerges from the Cumulative Distribution Function (CDF), which is known as Probit model or Normit model. If a variable $\mathrm{X}$ has normal distribution with mean $\mu$ and variance $\sigma^{2}$, its CDF is as in the following equation:

$F(X)=\int_{-\infty}^{X_{0}} \frac{1}{\sqrt{2 \sigma^{2} \pi}} e^{-(X-\mu)^{2}} / 2 \sigma^{2}$

where $X_{0}$ is some specified value of X (Gujarati, 2004).

In our dataset there were firms selling only to the domestic market and those engaged in export. To perform a Probit model, we assumed that the likelihood of the $i$ th firm to export or not depends on an un-observable utility index $\mathrm{I}_{i}$, known as latent variable, that is determined by the explanatory variables $\mathrm{X}_{i}$ fitted in the model. The larger the value of utility index $\mathrm{I}_{i}$, the greater the probability of the firm to export into regional and international markets. This can be expressed as in the following equation:

$I_{i}=\beta_{1}+\beta_{2} X_{i}$

where $X_{\mathrm{i}}$ can be the number of employees in the $i$ th firm.

Accordingly, we denote $\mathrm{Y}=1$ if the firm was engaged in export and $\mathrm{Y}=0$ if it serves only to domestic market. We assume that there is a threshold level of the index, denoted as $\mathrm{I}_{i}{ }^{*}$. If $\mathrm{I}_{i}>\mathrm{I}_{i}{ }^{*}$, the firm will export, otherwise it will not. Given the assumption of normality, the probability that $\mathrm{I}_{i}^{*}$ is less than or equal to $\mathrm{I}_{i}$ can be estimated from the standardized normal CDF as in Table 4:

Table 42. Results of probit estimation for initial model and with omitted variables

\begin{tabular}{lll}
\hline Variables & Coefficient & Coefficient \\
\hline Firm size & $0.014478^{* * *}$ & $0.013043^{* * *}$ \\
\hline Log-likelihood & -105.35 & -110.6780 \\
\hline R-squared & 0.581 & 0.560 \\
\hline
\end{tabular}

Note: Significance is denoted as follows: $* P<0.05 ; * * P<0.01 ; * * * P<0.001$.

The firm size was shown to be highly statistically significant and positively related, indicating thus the importance of economies of scale in the probability of firm being engaged in export. The Probit model was further extended into the Tobit model. In the Probit model we were interested in estimating the probability of a company 
being engaged in export as a function of the number of variables fitted in the model (Table 5).

Table 5. Results of tobit estimation for initial model

\begin{tabular}{lllll}
\hline Variable & Coefficient & Std. Error & z-Statistic & Prob. \\
\hline \hline Firm size & 0.010351 & 0.002004 & 5.165327 & 0.0000 \\
Constant & -2.752144 & 0.630437 & -4.365454 & 0.0000 \\
\hline
\end{tabular}

\subsubsection{Best fitted model of hierarchical regression}

A backward elimination method was used to remove non-significant explanatory variables introduced in the initial model. Regression coefficients of the best fitted model are presented in the following Table 6.

Table 6. Coefficients of the best fitted model

\begin{tabular}{llllll}
\hline (Constant) & Coefficient & Std. Error & t-Statistic & Prob. & VIF \\
\hline Firm size & -0.411 & 0.949 & -0.433 & 0.666 & 1.350 \\
(Constant) & 4.689 & 0.917 & 5.111 & 0.000 & 3.005 \\
\hline
\end{tabular}

R-squared: Model 1: 0.113 Model 2: 0.907

Adjusted R-squared: Model 1: 0.095 Model 2: 0.899

The obtained coefficients in the best fitted model of the regression analysis show that the number of employees in the company was positively correlated and significantly determining the percentage of export share in total sales (p-value = 0.0000). It indicates that if a company has one more employee, the percentage of the export share in total sales will increase by $0.45 \%$, keeping the other explanatory variables constant. From the standardized coefficients obtained it was possible to see that the size of a company in terms of the number of employees was the strongest predictor of the export share in total sales (Table 7).

Table 7. Calculation of the unique account of each predictor in the variance of export share in total sale

\begin{tabular}{|c|c|c|c|}
\hline Variables & Part & $\begin{array}{l}\text { Squared value of the semi-partial } \\
\text { measure }\end{array}$ & $\begin{array}{l}\text { Squared value of the } \\
\text { semi-partial measure*100 }\end{array}$ \\
\hline Firm size & 0.225 & 0.050625 & 5.0625 \\
\hline
\end{tabular}

Correlation coefficients presented in the part column indicate semi-partial measure and the squared values gave the unique contribution of the variance of export share in total sales that can be accounted by the size of the company (number of employees), marketing strategy, innovation and the financial barriers. It showed that $(0.225)^{2}=(0.050625 * 100)=5.06 \%$ of the variance of export share in total sale can be accounted for by the size of a company after all other predictors have been statistically controlled for. Therefore the research hypothesis can be stated as:

$H_{1}$ : Firm size (number of employees) is positively associated with export performance. 
The relationship between the firm size and export often yield discrepancies in the results due to different measures for size like the number of employees or the sales level of the firm (Verwaal and Donkers 2001; Gabbitas 2003; Kalafsky 2004; Majocchi 2005; Pla-Barber 2007). In terms of firm size both large and small ones comprise competitive advantages (Moen, 1999). Large firms influence export performance through the economies of scale and via share of common expenses greater than those for expanded markets (Majocchi et al, 2005). Small firms on the other side can compete more on the bases of product quality as well as their flexibility to enter and exit foreign markets (Bonaccorsi, 1992).

From various authors we have different relationship between firm size and export, if you want to be more competitive globally you have to be big (Lefebreve and Lefebreve, 2001). One thing is quite important that, most positive effect is if we measured size of firms based on total firm sales, and some negative effects if we measured size of firms based on number of employees (Kaynak and Kuan, 1993).

The positive impact justified by the fact, that you have more resources if you have a larger company, than this larger company can improve their performance from experience and also from economies of scale (Maurel, 2009). However small firms with high exports performance also exist, but based on initial capital, larger company has more opportunities to fulfill requirements of international trade by reducing transaction costs (Maurel, 2009). Some other authors found negative relationship between firm size and exports (James and Pett, 2000). Chetty and Hamilton (1993), analyzed more than 111 studies in order to proof about validity and significance of key variables, among them they confirm that firm size is a causal factor in export success. The obtained results from the study showed that there was a strong positive relationship between firm size measured with number of employees and the export performance of a company (Table 8).

Table 83. Correlation of firm size with the export share in total sale

\begin{tabular}{lllll}
\hline Variables & & $\begin{array}{l}\text { Pearson } \\
\text { Correlation }\end{array}$ & P-value & $\mathrm{H}_{3}$ \\
\hline Firm size & Export share in total sale (in \%) & $0.861^{* *}$ & 0.000 & Accepted \\
\hline
\end{tabular}

Note: Significance of variations is denoted as follows: $* P<0.05 ; * * P<0.01 ; * * * P<0.001$.

The obtained results from the study showed that there was a strong positive relationship between firm size measured with number of employees and the export performance of a company.

\section{Conclusion}

Moreover, a lot of studies stated that there is a significant positive impact of management's commitment to the export performance of a firm. A survey conducted by Julian and Nhat $\mathrm{Lu}$ (2007) states that the commitment of the management has a significant positive impact towards the performance of the export marketing of the 
firm or organization. Based on previous researches, Madsen (1989) and Aaby and Slater (1989) found a significant correlation between education staff of firms on reaching better performance and the degree of internationalization (Dominguez et al., 1993) and attitudes toward better future exports (Gripsrud, 1990).

The obtained results from the conducted questionnaire of SMEs in Kosovo, concerning the dependency of managers' education and training were corresponding with those attained when testing dependency of managers' age and the international experience. Literature review shows a different relationship between firm size and export. According to Lefebreve and Lefebreve (2001), if you want to be more competitive globally you have to be significant. But, these correlations depend on how the firm size is measured, with the number of employees or with the firm's sales total.

The actual collision is reasoned by the fact that there are more resources to a larger company, and larger companies can improve their performance by relying on the experience (Maurel, 2009). This positive correlation can also be seen in this research for exporter SMEs in Kosovo when firm size is positively and strongly correlated with export performance.

\section{References:}

Aaby, N.E., Slater, S.F. 1989. Management influences on export performance: a review of the empirical literature 1978-88. International marketing review, 6(4), 7-23.

Archarungroj, P., Hoshino, Y. 1998. The Impact of Firm Size on Export Performance and Attitudes. Japanese Journal of Administrative Science, 12(2), 79-88.

Babakus, E., Yavas, U., Haahti, A. 2006. Perceived uncertainty, networking and export performance: A study of Nordic SMEs. European Business Review, 18(1), 4-13.

Bilkey, W.J., Tesar, G. 1977. The export behavior of smaller-sized Wisconsin manufacturing firms. Journal of international business studies, 8(1), 93-98.

Bonaccorsi, A. 1992. On the relationship between firm size and export intensity. Journal of international business studies, 23(4), 605-635.

Calof, J.L., Beamish, P.W. 1995. Adapting to foreign markets: Explaining internationalization. International business review, 4(2), 115-131.

Cavusgil, S. T., Zou, S. 1994. Marketing strategy-performance relationship: an investigation of the empirical link in export market ventures. Journal of marketing, 58(1), 1-19.

Chetty, S.K., Hamilton, R.T. 1993. Firm-level determinants of export performance: a metaanalysis. International Marketing Review, 10(3).

Czinkota, M.R., Johnston, W.J. 1983. Exporting: does sales volume make a difference? Journal of International Business Studies, 14(1), 147-151.

Dholakia, R.H., Kapur, D. 2004. Determinants of export performance of Indian firms: a strategic perspective, 1 .

Gripsrud, G. 1990. The determinants of export decisions and attitudes to a distant market: Norwegian fishery exports to Japan. Journal of International Business Studies, 21(3), 469-483. 
Hirdinis, M. 2019. Capital Structure and Firm Size on Firm Value Moderated by Profitability. International Journal of Economics and Business Administration, 7(1), 174-191.

Holzmüller, H.H., Stöttinger, B. 1996. Structural modeling of success factors in exporting: cross-validation and further development of an export performance model. Journal of International Marketing, 4(2), 33-52.

Kaplan, S. 1989. The effects of management buyouts on operating performance and value. Journal of financial economics, 24(2), 213-252.

Katsikeas, C.S., Leonidou, L.C., Morgan, N.A. 2000. Firm-level export performance assessment: review, evaluation, and development. Journal of the Academy of Marketing Science, 28(4), 493-511.

Kaynak, E., Kuan, W.K.Y. 1993. Environment, strategy, structure, and performance in the context of export activity: an empirical study of Taiwanese manufacturing firms. Journal of Business Research, 27(1), 33-49.

Kleinschmidt, E.J., Cooper, R.G. 1995. The relative importance of new product success determinants - Perception versus reality. R\&D Management, 25(3), 285-296.

Kneller, R., Pisu, M. 2006. The role of experience in export market entry: Evidence for UK Firms. Available at SSRN 951982.

Leonidou, L.C., Katsikeas, C.S. 2010. Integrative assessment of exporting research articles in business journals during the period 1960-2007. Journal of Business Research, 63(8), 881-885.

Maurel, C. 2009. Determinants of export performance in French wine SMEs. International Journal of Wine Business Research, 21(2), 118-142.

Majocchi, A., Bacchiocchi, E., Mayrhofer, U. 2005. Firm size, business experience and export intensity in SMEs: A longitudinal approach to complex relationships. International Business Review, 14(6), 719-738.

Majumdar, S.K. 1997. The impact of size and age on firm-level performance: some evidence from India. Review of industrial organization, 12(2), 233-239.

Miller, D., Friesen, P.H. 1984. A longitudinal study of the corporate life cycle. Management science, 30(10), 1163-1181.

Moen, P. 2003. Linked lives: Dual careers, gender, and the contingent life course. Social dynamics of the life course: Transitions, institutions, and interrelations, 1(1), 237 258.

Moen, P., Han, S.K. 2001. Gendered Careers. Working families: The transformation of the American home, 45-53.

Morgan, N.A., Katsikeas, C.S., Vorhies, D.W. 2012. Export marketing strategy implementation, export marketing capabilities, and export venture performance. Journal of the Academy of Marketing Science, 40(2), 276-287.

Nazar, M.S., Shaikh, F.M. 2011. Determinant of export performance of small \& medium enterprises. J Bus Strateg, 5(1), 22-29.

OECD. 1997. The OECD report on regulatory reform. OECD.

Rose, G.M., Shoham, A. 2002. Export performance and market orientation: establishing an empirical link. Journal of Business Research, 55(3), 217-225.

Rupeika-Apoga, R., Saksonova, S. 2018. SMEs' Alternative Financing: The Case of Latvia. European Research Studies Journal, 21(3), 43-52, DOI: 10.35808/ersj/1042.

Samiee, S., Walters, P.G. 2002. Export education: perceptions of sporadic and regular exporting firms. International Marketing Review, 19(1), 80-97. 